\title{
Ohmic heating as an innovative approach for the production of keratin films
}

\author{
Ana Tinoco ${ }^{\mathrm{a}}$, Rui M. Rodrigues ${ }^{\mathrm{a}}$, Raul Machado ${ }^{\mathrm{b}}$, Ricardo N. Pereira ${ }^{\mathrm{a}}$, Artur Cavaco-Paulo ${ }^{\mathrm{a}}$, Artur Ribeiro ${ }^{\mathrm{a}, *}$ \\ a CEB-Centre of Biological Engineering, University of Minho, Campus of Gualtar, 4710-057 Braga, Portugal \\ b CBMA (Centre of Molecular and Environmental Biology), Department of Biology, University of Minho, Campus de Gualtar, 4710-057 Braga, Portugal
}

\section{A R T I C L E I N F O}

Article history:

Received 20 December 2019

Received in revised form 31 January 2020

Accepted 12 February 2020

Available online $\mathrm{xxxx}$

\section{Keywords:}

Conventional heating

Films

Hair model

Ohmic heating

Keratin

\begin{abstract}
A B S T R A C T
Ohmic heating is a thermal processing method based on the application of electric fields directly into a semiconductive medium. In this study, we explored for the first time the use of ohmic heating to obtain keratin films. The properties of the films prepared by ohmic heating and conventional heating were evaluated and compared under similar thermal profiles. A lower increase in free thiols' concentration was obtained for the keratin solutions and keratin films submitted to ohmic heating ( $16 \%$ increase for the keratin solution extracted from virgin hair, $\mathrm{pH} 9$, submitted to ohmic heating and $23 \%$ when submitted to conventional heating). Significant differences in the swelling results were observed for the films prepared with keratin extracted from virgin hair, with a swelling decrease in about 55\% for the films prepared by ohmic heating. Generally, the keratin films obtained by ohmic heating showed distinct properties comparatively to the films produced by conventional methods. The application of a fusion protein on the keratin films demonstrated their capacity to be used as substitutes to hair fibers when evaluating the potential of new cosmetic products. This work suggests that ohmic heating show potential to tailor keratin films properties depending on an intended application or functionality.
\end{abstract}

(C) 2020 Published by Elsevier B.V.

\section{Introduction}

Protein unfolding and aggregation occur in different extents depending on the $\mathrm{pH}$, ionic strength and temperature, affecting the final properties of the protein-based materials [1]. During heating of a protein solution, the three-dimensional structure of the protein is modified through the unfolding of the polypeptide chains, exposing the internal sulfhydryl groups and the hydrophobic side chains buried in the interior of the native molecule. These structural changes will influence the filming ability of the proteins and the properties of the protein-based films.

Ohmic heating was used in this study as a new and alternative procedure for the use of conventional heating methods - i.e. a water bath with controlled temperature - in the keratin denaturation process and keratin films' preparation. The final properties of the keratin films prepared by ohmic or conventional heating were compared in order to evaluate the effects of each heating method on the protein films. The ohmic heating is an emergent thermal process where electric currents

\footnotetext{
* Corresponding author at: CEB-Centre of Biological Engineering, University of Minho Campus of Gualtar, 4710-057 Braga, Portugal

E-mail addresses: catarinamalheiro@ceb.uminho.pt (A. Tinoco),

ruirodrigues@ceb.uminho.pt (R.M. Rodrigues), raulmachado@bio.uminho.pt (R. Machado), rpereira@deb.uminho.pt (R.N.Pereira), artur@deb.uminho.pt (A. Cavaco-Paulo), arturibeiro@ceb.uminho.pt, arturibeiro@ceb.uminho.pt (A. Ribeiro).
}

pass through a semi-conductive solution allowing a direct or volumetric heating process. This electro-heating method is recognized by reducing excessive coagulation or the complete denaturation of the protein structure [2]. During ohmic heating, the non-thermal effects exerted by the presence of a moderate electric field has been described as potential vector of alteration of proteins interactions thus changing the final properties of the developed protein films [3].

Keratin proteins are found in the cytoplasm of almost all differentiated eukaryote cells, being mainly known as the principal structural proteins of hair, wool and skin [4]. The term 'keratin' includes a complex mixture of proteins, such as keratins and keratin-associated proteins [5]. Considering the disulphide bonds content, keratins can be classified as soft or hard keratins. The soft keratins, with a low content of disulphide bonds, are found in the stratum corneum and in the callus, whereas the hard keratins, with a high disulphide content, are found in epidermal appendages such as feathers, hair, nails, horns, and hoofs [4]. At a molecular level, the most distinctive feature of keratins is the high concentration of cysteine (Cys) residues (7-20\% of the total amino acid residues) [4]. Cys is a non-polar amino acid that contains sulfur groups which can form sulfur-sulfur (S-S) cystine bonds with other intra- or intermolecular Cys molecules. The cross-links between intermolecular cystine bonds together with other protein structural features, like crystallinity and hydrogen-bonding, gives keratin its high strength and stiffness [6]. Due to its structure, keratin proteins are only soluble in solutions containing denaturing agents like urea, and reducing agents such as 
mercaptoethanol, which are capable to cleave the keratin disulphide bonds [4]. The keratin hydrolysates can be used in different applications: as odor-removing or deodorizing composition [7], included in skin-hair care cosmetic [8,9], in the enrichment of wheat straw for ruminant diets [10] or applied in the packaging of goods [11]. Also, the keratin proteins are widely used in the biomedical field, for wound healing [12], ocular [13] and nerve regeneration [14] and bone tissue engineering [15]. Keratins were also included in the development of drug delivery systems with controlled release due to keratin stability, low reactivity, and good mechanical and structural properties [16]. In cosmetic applications, keratin-based particles were developed to improve the mechanical and thermal properties of virgin and overbleached hair [9].

The aim of the present study was to evaluate the effect of the heating method (conventional vs ohmic heating), $\mathrm{pH}$ and keratin source (virgin vs overbleached hair) on the properties of keratin films. We also assessed the potential of these keratin films to be used as models for the screening of the effect of protein-based cosmetic formulations on hair. To assure that the differences observed for the keratin filmforming solutions and the keratin films were only related with the type of heating, $\mathrm{pH}$ and keratin source, the concentration of the keratin solutions and the time and heating profile, were maintained identical along the study.

\section{Experimental}

\subsection{Materials}

Caucasian black human hair samples were provided by a local hairdresser. The detergent compatible (DC) protein assay kit and the Ellman's reagent were obtained from Bio-Rad, Portugal. Glycerol and formaldehyde were supplied by Fisher Scientific, Portugal, and all other chemicals were supplied by Merck, Spain.

\subsection{Extraction and purification of keratin}

The keratin used to produce the films was extracted from human hair donated from a local hairdresser salon. The hair samples were first washed according to the IAEA/RL/50 1978 recommendations to remove all contaminants and lipids and the protocol for keratin extraction was adapted from Ayutthaya et al. [17]. The final keratin solution was quantified by DC method according to manufacture protocol and was concentrated to a final concentration around $30 \mathrm{mg} / \mathrm{mL}$.

\subsection{Hair overbleaching}

Hair samples were subjected to five bleaching cycles using a commercial kit (Revlon Professional ${ }^{\circ}$ ) following the manufacture guidelines. After bleaching, the overbleached hair was washed with a commercial shampoo (Pantene ${ }^{\circledR}$ Basic) and dried overnight. The keratin was extracted from the overbleached hair using the protocol previously described.

\subsection{Heating treatment of keratin solutions}

\subsubsection{Conventional heating}

Conventional heating experiments were performed in a water bath (Grant Instruments, OLS200, Cambridge, United Kingdom) and the increase in the temperature during the heating process was measured using a digital thermometer placed at the center of the sample volume. The keratin solutions selected for the conventional heating had a concentration between 30 and $35 \mathrm{mg} / \mathrm{mL}$ and the treatments were performed for a total of $53 \mathrm{~min}$ : $23 \mathrm{~min}$ heating time plus $30 \mathrm{~min}$ at $85^{\circ} \mathrm{C}$, with constant agitation.

\subsubsection{Ohmic heating}

The ohmic heating of the keratin solutions was performed on a glass cylinder containing stainless steel electrodes at each edge, as described by Pereira et al., 2010 [3]. The conductivity of the samples allowed studying the effect of the ohmic heating on the keratin films (conductivity between 20 and $120 \mu \mathrm{S} / \mathrm{cm}$ ). The treatments were performed for a total of $53 \mathrm{~min}: 23 \mathrm{~min}$ of heating time plus $30 \mathrm{~min}$ at $85^{\circ} \mathrm{C}$. The heating kinetics and thermal profile were kept similar for ohmic heating and conventional heating treatments. The temperature was controlled by regulating the voltage output of a function generator $(1 \mathrm{~Hz}-25 \mathrm{MHz}$ and 1 to $10 \mathrm{~V}$; Agilent 33220A, Penang, Malaysia) and then amplified on an amplifier system (Peavey CS3000, Meridian, MS, USA). The electric fields used ranged from 7 to $24 \mathrm{~V} / \mathrm{cm}$ and applied as sine waves at a frequency of $25.000 \mathrm{~Hz}$. Temperature was measured with a type $\mathrm{K}$ thermocouple (Omega Engineering, Inc., Stamford, CT, USA), connected to a data logger (USB-9161, National Instruments Corporation, Austin, TX, USA). During the treatments the samples were gently stirred (with a magnetically stirrer) to ensure homogeneity.

\subsection{Preparation of keratin films}

The keratin solutions treated by ohmic and conventional heating were used to produce the keratin films. A plasticizer agent (glycerol $1 \% \mathrm{w} / \mathrm{w}$ ) was added to the keratin solutions and the samples were incubated in an ultrasound bath for $15 \mathrm{~min}$ followed by $10 \mathrm{~min}$ on ice. A volume corresponding to $29 \mathrm{mg}$ of keratin was added to Teflon molding rings with $1 \mathrm{~cm}$ inner diameter [18]. The molding rings containing the protein solutions were placed on a vacuum chamber overnight, at room temperature, to minimize the appearance of bubbles on the films' surface. The keratin solutions were then dried at $40{ }^{\circ} \mathrm{C}$ for $24 \mathrm{~h}$ and then the temperature was increased to $110^{\circ} \mathrm{C}$ for $4 \mathrm{~h}$ for the curing of the films. This curing was essential to remove the films from the mold and oxidize the disulphide bridges between keratin molecules, producing more stable films. The films were stored in an excicator until use. To study the effect of the type of keratin and the $\mathrm{pH}$ on the films' properties, we used keratin extracted from virgin and from overbleached hair with the $\mathrm{pH}$ of the keratin solutions being adjusted to $7,8,9$ and 10 prior heating.

\subsection{Keratin films' cross-linking induced by formaldehyde}

To induce the cross-linking, the keratin films were treated with formaldehyde $37 \mathrm{wt} \%$ in water. Initially, the keratin films were incubated overnight with formaldehyde vapor, at room temperature. Then, each film was incubated with $3 \mathrm{~mL}$ of formaldehyde $37 \mathrm{wt} \%$ in water for $24 \mathrm{~h}$. The films were then removed from the formaldehyde, dried with a filter paper and incubated at $50{ }^{\circ} \mathrm{C}$ until completely dried [19].

\subsection{Characterization of keratin film-forming solutions}

\subsubsection{Formation of keratin aggregates}

The average size of keratin aggregates formed during the heating treatments at $85^{\circ} \mathrm{C}$ was measured by dynamic light scattering using a Zetasizer from Malvern Instruments, Nano-ZS. For this analysis, $50 \mu \mathrm{L}$ of keratin solution was dispersed in $950 \mu \mathrm{L}$ of ultrapure water and analyzed at $25{ }^{\circ} \mathrm{C}$. The values for viscosity and refractive index were $0.8872 \mathrm{cP}$ and 1.330 , respectively. Each sample was measured in triplicate, and the results are presented as mean value \pm standard deviation [20].

\subsubsection{Determination of Free thiol content}

The amount of free thiol groups in the keratin samples was determined spectrophotometrically using 5,5'-dithiobis(2-nitrobenzoic acid) (Ellman's reagent). Briefly, $100 \mu \mathrm{L}$ of keratin solution was added to $500 \mu \mathrm{L}$ of $0.5 \mathrm{M}$ phosphate buffer, $\mathrm{pH} 8.0$, containing $10 \mu \mathrm{L}$ of Ellman's reagent solution $(4 \mathrm{mg} / \mathrm{mL})$ in $0.5 \mathrm{M}$ phosphate buffer, $\mathrm{pH}$ 8.0. The 
samples were mixed and incubated for $1 \mathrm{~h}$ at room temperature, in dark. Absorbance was then measured at a wavelength of $412 \mathrm{~nm}$, and the amount of free thiol groups were determined taking in consideration a standard curve obtained using L-Cys [21].

\subsection{Characterization of keratin films}

\subsubsection{Determination of free thiol content}

The amount of free thiol groups in the keratin films was determined using the protocol previously described, with the keratin solutions being replaced by the keratin films and the solution volumes increased $10 \times$.

\subsubsection{Swelling ratio and water solubility}

To measure the swelling ratio of the keratin films, three films of each condition were weighted and immersed in $10 \mathrm{~mL}$ of distilled water in petri dishes sealed with parafilm and placed in a thermostatic bath at $25{ }^{\circ} \mathrm{C}$. After $1 \mathrm{~h}$ of incubation time, the films were taken from the water, the excess of liquid on the surface was removed with a tissue paper and the films were weighted again. The swelling ratio (\%) was calculated using the Eq. (1):

Swelling ratio $(\%)=\frac{\text { Weight }_{f}-\text { Weight }_{0}}{\text { Weight }_{0}} \times 100$

where Weight $\mathrm{f}_{\mathrm{f}}$ corresponds to the film weight after $1 \mathrm{~h}$ of incubation and Weight $t_{0}$ correspond to the film's dry weight before immersion on distillated water.

The solubility of the films in water was determined after incubation of the keratin films in distillated water for $24 \mathrm{~h}$. The films were removed from the water, dried at $100{ }^{\circ} \mathrm{C}$ for $24 \mathrm{~h}$ in a dry oven and then the solids content was measured. The water solubility (\%) was determined using Eq. (2):

Water solubility $(\%)=\frac{\text { Weight }_{0}-\text { Weight }_{f}}{\text { Weight }_{0}} \times 100$

where Weight $_{\mathrm{f}}$ corresponds to the film weight after incubation and Weight $_{0}$ to the film's dry weight before immersion on distillated water. Both swelling rate and water solubility data corresponds to the average of three measurements [22].

\subsubsection{Secondary structure analysis}

FTIR measurements were recorded on a Perkin Elmer Spectrum$\mathrm{Two}^{\mathrm{TM}}$ IR spectrometer with a deuterated triglycine sulfate (DTGS) detector and $\mathrm{KBr}$ beam splitter, coupled with an UATR ( single reflection diamond, Perkin Elmer) accessory. Atmospheric $\mathrm{CO}_{2} / \mathrm{H}_{2} \mathrm{O}$ was automatically subtracted during spectra collection. Spectra were acquired at room temperature from $4000 \mathrm{~cm}^{-1}$ to $400 \mathrm{~cm}^{-1}$ and collected after 64 scans with a resolution of $4 \mathrm{~cm}^{-1}$. Baseline subtraction, normalization, second derivative and band fitting were performed with OriginPro 9.0 (OriginLab, Northampton, MA).

\subsubsection{Morphological observation}

The samples were characterized using a desktop Scanning Electron Microscope (SEM) (Phenom ProX, Netherlands). All results were acquired using the ProSuite software. The keratin films samples were added to aluminium pin stubs with electrically conductive carbon adhesive tape (PELCO Tabs ${ }^{\mathrm{TM}}$ ). Before analysis, the samples were covered with 20 Å of gold to improve samples electrical conductivity.

\subsubsection{Thermal gravimetric analysis}

TGA of keratin films was performed with a TGA 4000 (Perkin Elmer, Waltham, MA, US) using an alumina crucible with sample weights of 8-10 mg. The temperature calibration was done by Curie temperatures of reference materials: alumel, nickel and perkalloy at the same sample scanning rate. The measurements were performed from 25 to $800{ }^{\circ} \mathrm{C}$ at $20^{\circ} \mathrm{C} / \mathrm{min}$ under a nitrogen atmosphere (flow rate: $20 \mathrm{~mL} / \mathrm{min}$ ). The weight loss, in percentage, and its derivative were represented as function of temperature. The data were acquired using Pyris software (version 13).

\subsection{Increase of films opacity using KP-Crystallin fusion proteins}

For this assay, keratin films prepared at pH 9, and submitted to conventional and ohmic heating, were incubated with two crystallin-based fusion proteins (KP-Cryst Wt and KP-Cryst Mut) [23]. The increase of keratin films opacity was achieved by adding $100 \mathrm{uL}$ of $1 \mathrm{mg} / \mathrm{mL}$ of KP-Cryst Wt/Mut solutions to the surface of the films. After application of the proteins, the films were incubated at room temperature until completely dried. This procedure was repeated 6 times. Films incubated with ultrapure water added to the surface were used as controls. Opacity was calculated through the ratio between reflectance and reflectivity (Chroma Meter CR-400, Konica Minolta, Japan).

\subsection{Statistical analysis}

Data are presented as average standard deviation (SD) of three assays. Statistical comparisons were performed by one-way ANOVA with GraphPad Prism 5.0 software (La Jolla, CA, USA). Tukey's posthoc test was used to compare all the results between them, and Dunnett's test was used to compare the results with a specific control. A $p \leq .05$ was considered to be statistically significant.

\section{Results and discussion}

\subsection{Characterization of keratin film-forming solutions}

\subsubsection{Proteins' aggregation profiles}

The denaturation of proteins involves the breaking of individual covalent bonds between the atoms of the polypeptide backbone. This process is usually accompanied by the aggregation, coagulation or gelation of the proteins' molecules. The conversion between the folded and unfolded state of proteins can be induced by changes in temperature, pressure, $\mathrm{pH}$, chemical denaturants or solvent nature [24].

When the keratin solutions were heated at $85{ }^{\circ} \mathrm{C}$ for $30 \mathrm{~min}$, a change was observed on the average hydrodynamic diameter of the protein particles' size, independently on the type of heating and type of keratin - Table 1. For the keratin obtained from overbleached (OB) hair there was an increase on particles size regardless of the $\mathrm{pH}$ (data not shown). Nevertheless, for the keratin obtained from the virgin hair, the $\mathrm{pH}$ of the solutions governed the proteins aggregation profiles, with a decrease of particles size being observed for $\mathrm{pH}$ values between 7 and 9, while an increase was observed for $\mathrm{pH} 10$. Alkaline $\mathrm{pH}$ values are described to contribute to the disruption of Cys in the keratin molecules, and favor the occurrence of some side reactions as the hydrolysis of peptide and amide bonds, and the formation of new cross-links as lanthionine or lysinoalanine [25]. These factors could benefit the interaction between different molecules of keratin proteins at higher $\mathrm{pH}$ values, increasing the final aggregates size.

Regarding the variation of the keratin solution polydispersity index (PdI), there was a decrease in the PdI after heating for both types of keratin and for all the $\mathrm{pH}$ values. Before heating, the keratin solutions presented a polymodal distribution, however, after $30 \mathrm{~min}$ at $85^{\circ} \mathrm{C}$, the particles' population becomes less polydisperse, and in some conditions the size distribution became monomodal (represented by $100 \%$ of percentage population in Table 1 ).

Analyzing the effect of $\mathrm{pH}$ on the protein particles' size after heating, an increase in the aggregates size was observed with the increase in the $\mathrm{pH}$ of the keratin solutions. This behavior could be due to the fact that higher $\mathrm{pH}$ leads to an increase in protein charge, which could stabilize the aggregates by the formation of specific charge interactions like salt 
Table 1

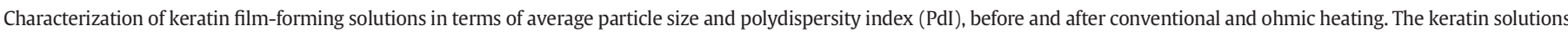
were heated for $30 \mathrm{~min}$ at $85^{\circ} \mathrm{C}$.

\begin{tabular}{|c|c|c|c|c|c|c|}
\hline \multirow[t]{2}{*}{ Keratin Hair Source } & \multirow[t]{2}{*}{$\mathrm{pH}$} & \multirow[t]{2}{*}{ Incubation time (min) } & \multicolumn{2}{|c|}{ Conventional heating } & \multicolumn{2}{|l|}{ Ohmic heating } \\
\hline & & & Size $(\mathrm{nm})$ & $\mathrm{PdI}^{\mathrm{b}}$ & Size (nm) & $\mathrm{PdI}^{\mathrm{b}}$ \\
\hline Virgin & 7 & 0 & $565.5(58.2 \%)^{\mathrm{a}}$ & 0.598 & $523.0(50.5 \%)^{\mathrm{a}}$ & 0.506 \\
\hline Virgin & 7 & 30 & $331.9(78.6 \%)^{a}$ & 0.535 & $213.3(75.4 \%)^{a}$ & 0.432 \\
\hline Virgin & 8 & 0 & $1348(69.2 \%)^{a}$ & 1.000 & $1987(44.1 \%)^{\mathrm{a}}$ & 1.000 \\
\hline Virgin & 8 & 30 & $486.7(100 \%)^{a}$ & 0.263 & $861.5(71.7 \%)^{a}$ & 0.879 \\
\hline Virgin & 9 & 0 & $735.5(85.8 \%)^{\mathrm{a}}$ & 0.510 & $1138(47.3 \%)^{\mathrm{a}}$ & 0.551 \\
\hline Virgin & 9 & 30 & $547.7(92.6 \%)^{a}$ & 0.402 & $957.5(75.5 \%)^{\mathrm{a}}$ & 0.424 \\
\hline Virgin & 10 & 0 & $613.3(71 \%)^{a}$ & 0.867 & $714.4(73.3 \%)^{a}$ & 0.737 \\
\hline Virgin & 10 & 30 & $780.2(92 \%)^{a}$ & 0.462 & $776.9(90.8 \%)^{a}$ & 0.606 \\
\hline $\mathrm{OB}^{\mathrm{C}}$ & 9 & 0 & $623.7(88.1 \%)^{\mathrm{a}}$ & 0.600 & $623.7(88.1 \%)^{a}$ & 0.600 \\
\hline $\mathrm{OB}^{\mathrm{c}}$ & 9 & 30 & $979.2(100 \%)^{a}$ & 0.500 & $700.6(100 \%)^{\mathrm{a}}$ & 0.481 \\
\hline
\end{tabular}

a Percentage of population corresponding to a specific size.

b Polydispersity index.

c Only reported the results for $\mathrm{pH}$ 9, data is not shown for the other $\mathrm{pH}$ values.

bridges or ion pairing [26]. Moreover, the differences in keratin samples' population observed on Table 1 could also be related with keratin solution's conductivity [3]. An increase in solution's conductivity was observed with increasing $\mathrm{pH}$ of the keratin solutions. Also, the keratin solution extracted from overbleached hair, presented a very low conductivity when compared to the keratin extracted from virgin hair. The differences in solution conductivity could be due to the different nature of the electrolyte (keratin protein vs degraded keratin), the protein hydration and the aggregates shapes [27], as well as the protein ions present in the solution [28]. These differences in the conductivity may also explain the observed variation of the particles size, since different electric fields were applied to the keratin solutions to achieve the same temperature profiles.

\subsubsection{Free thiol determination}

Keratin is a unique protein because it contains a large amount of the amino acid Cys when compared to other proteins. As referred previously cysteine is a sulfur-containing amino acid and can form sulfursulfur $(S-S)$ cystine bonds with other intra- or intermolecular cysteine molecules. Free thiol groups before and after heating were quantified using Ellman's reagent and are represented on Table 2.

Taking all data in consideration, it was observed, for both types of heating, an increase in the keratin free thiol content after heating. This was expected since thermal processing at denaturation temperatures involves changes in protein conformation that can convert masked $\mathrm{SH}$ groups into free $\mathrm{SH}$ groups, thus becoming available for the formation of covalent disulphide bonds [1] or reaction with the Ellman's reagent.

After incubation at $85^{\circ} \mathrm{C}$, significant differences in thiols' concentration were verified between the conventional and the ohmic heating for the keratin solutions prepared from virgin hair $(p<.01)$. For these solutions, a higher increase in thiols concentration was verified for the conventional heating when compared with the ohmic heating for all the tested $\mathrm{pH}$ values. However, when the keratin solutions were prepared from OB hair, no significant differences $(p>.05)$ between the two types of heating were verified in the thiols' concentration after heating. The higher reactivity of SH groups for the solutions submitted to conventional heating, was previously described by Pereira et al., 2010, using whey solutions to obtain protein films [3]. The results here obtained can be explained by the differences between the conventional and the ohmic heating, suggesting that the structural transitions and the keratin unfolding were more favored during the conventional heating, possibly due to more aggressive thermal effects [1,3]. Denaturation kinetics are primarily driven by covalent bonding of unfolded proteins, which in turn is closely related to the availability and reactivity of the free SH groups of unfolded proteins [1], being these more pronounced for the conventional heating.

Analyzing the effect of $\mathrm{pH}$ on thiols concentration, the same trend was observed for the two types of heating, with a higher sensitivity to variations on $\mathrm{pH}$ being obtained for the conventional heating. The higher sensitivity for the conventional heating could be related with the effect of the total net charges or local amino acids charge on the final protein structure, like the localization of free SH groups on the protein surface. For example, the effect of $\mathrm{pH}$ on Cys make it changes its net charge from neutral to negative between $\mathrm{pH} 7$ and $\mathrm{pH} 8$, so its responsiveness and reactivity with other groups is affected by the variations on $\mathrm{pH}[29]$.

\subsection{Characterization of keratin films}

\subsubsection{Free thiol determination}

After keratin films preparation and insolubilization using the formaldehyde, the concentration of free thiols on the films was determined, with the results for the films prepared at $\mathrm{pH} 9$ being presented in Table 3. Comparing with the keratin solutions before casting (Table 2), it was observed that the free thiol concentration on the keratin films is much lower. These lower values can be attributed to the films curing

Table 2

Effect of conventional and ohmic heating on the thiols' concentration of keratin film-forming solutions, after treatments at $85{ }^{\circ} \mathrm{C}$ for 30 min.

\begin{tabular}{|c|c|c|c|c|c|c|}
\hline \multirow[t]{2}{*}{ Keratin Hair Source } & \multirow[t]{2}{*}{$\mathrm{pH}$} & \multirow[t]{2}{*}{ Incubation time (min) } & \multicolumn{2}{|c|}{ Conventional heating } & \multicolumn{2}{|l|}{ Ohmic heating } \\
\hline & & & Thiols (mM) & Thiols increase (\%) & Thiols (mM) & Thiols increase (\%) \\
\hline Virgin & 7 & 0 & $0.431 \pm 0.002$ & - & $0.351 \pm 0.015$ & - \\
\hline Virgin & 7 & 30 & $0.705 \pm 0.013$ & 64.69 & $0.549 \pm 0.018$ & 56.45 \\
\hline Virgin & 8 & 0 & $0.454 \pm 0.01$ & - & $0.437 \pm 0.015$ & - \\
\hline Virgin & 8 & 30 & $0.730 \pm 0.012$ & 60.62 & $0.586 \pm 0.015$ & 34.02 \\
\hline Virgin & 9 & 0 & $0.666 \pm 0.019$ & - & $0.516 \pm 0.009$ & - \\
\hline Virgin & 9 & 30 & $0.820 \pm 0.001$ & 23.12 & $0.598 \pm 0.007$ & 15.98 \\
\hline Virgin & 10 & 0 & $0.334 \pm 0.0028$ & & $0.492 \pm 0.017$ & \\
\hline Virgin & 10 & 30 & $0.811 \pm 0.001$ & 59.12 & $0.869 \pm 0.029$ & 43.44 \\
\hline $\mathrm{OB}$ & 9 & 0 & $0.0859 \pm 0.001$ & & $0.086 \pm 0.001$ & \\
\hline OB & 9 & 30 & $0.145 \pm 0.001$ & 69.26 & $0.150 \pm 0.008$ & 74.39 \\
\hline
\end{tabular}


Table 3

Effect of conventional and ohmic heating on the thiols' concentration of keratin films ${ }^{1}$, after curing at $110^{\circ} \mathrm{C}$ for $4 \mathrm{~h}$ and insolubilization with formaldehyde.

\begin{tabular}{lll}
\hline Keratin hair source & \multicolumn{1}{l}{ Thiols $(\mathrm{mM})$} \\
\cline { 2 - 3 } & Conventional heating & Ohmic heating \\
\hline Virgin & $0.0253 \pm 0.000557^{\text {ac }}$ & $0.0187 \pm 0.00156^{\text {ad }}$ \\
OB & $0.0108 \pm 0.000457^{\text {bc }}$ & $0.00624 \pm 0.000446^{\text {bd }}$ \\
\hline
\end{tabular}

The data with the same superscripts (a,b,c, and d) are significantly different between them $(p<.05)$.

1 The films were prepared with keratin extracted from virgin or overbleached hair and the $\mathrm{pH}$ adjusted to 9 .

at $110^{\circ} \mathrm{C}$ for $4 \mathrm{~h}$, a process essential to oxidize the disulphide bridges between keratin molecules, producing more stable films with improved properties [18] Also, the free thiols concentration is affected by films insolubilization with the formaldehyde that promote Cys cross-linking, also increasing the films stability [19]. The same behavior was observed for the keratin films prepared at $\mathrm{pH} 7,8$ and 10 , with a decrease in the thiols' concentration of films when compared to the keratin filmforming solution (data not shown).

\subsubsection{Swelling ratio and water solubility}

To understand the effect of heating on the ability of the keratin films to swell and/or degrade when in contact with water, we evaluated the swelling ratio and water solubility of the keratin films obtained from the keratin solutions heated by conventional or ohmic heating (Fig. 1 and Fig. 2).

During the keratin films preparation, it was necessary to add glycerol to the keratin film-forming solutions to avoid films brittleness after drying. Glycerol was able to improve films flexibility by decreasing the inter and intramolecular attractive forces and increase chain mobility [22].

Ideally, the regeneration of disulphide bonds in the keratin films during the curing at $110^{\circ} \mathrm{C}$ should be sufficient to impart water insolubility and good mechanical properties to the resultant films. However, as represented on Figs. 1A and 2A, it was observed that the insolubilization by temperature was not enough with regard to keratin films' water solubility and swelling ratio. The films prepared with keratin from virgin hair adjusted to $\mathrm{pH} 9$ and submitted to conventional heating, presented water solubility and swelling ration values of $26.21 \pm 0.078 \%$ and $597.12 \pm 68.52 \%$, respectively. To promote the insolubilization of the keratin films they were incubated with formaldehyde (vapor and liquid). Formaldehyde is described by many authors as the most effective cross-linker in reducing water solubility [30]. Formaldehyde have access to some reactive groups in amino acids like Cys, Hys and Lys, resulting in the formation of covalent bonds, what leads to an increase in the degree of reticulation and greater polymeric matrix structuring. As a consequence, a reduction in chain mobility is verified, producing more cohesive protein chains and more resistant films, resulting in films with lower water permeability [30].

The effect of insolubilization on the water solubility and swelling ratio of the keratin films, promoted by the formaldehyde, was evident for all the $\mathrm{pH}$ values, type of keratin and heating method. Regarding the water solubility, and comparing with the films before insolubilization, there was a decrease between 9 and 30\% for the keratin films obtained by conventional heating and between 25 and 40\% for the films obtained by ohmic heating. The significant decrease on the water solubility was dependent on the $\mathrm{pH}$ (higher decrease for lower $\mathrm{pH}$ values) and on the heating method (higher decrease for the ohmic heating). The lower improvement observed for the higher pHs could be related with differences in the reactivity of the Cys groups available to interact with formaldehyde and to form stable linkages [29]. This amino acid shows a high responsiveness to changes in physiological states and environmental conditions which affect its ability to interact with other proteins or charged molecules [29].

The higher decrease on water solubility observed for the ohmic heating, could be related with keratin structural transitions and unfolding caused by the ohmic heating which can affect in a different way the availability and reactivity of the free $\mathrm{SH}$ groups from the keratin protein [1]. The differences in the availability and reactivity of the Cys groups can increase the cross-linking degree obtained from the reaction of formaldehyde with the free Cys residues on the keratin, what may also affect the alignment of the polymeric keratin structure resulting in a decrease in the films' water solubility [31]. The aggregates sizes of keratin film-forming solution could also affect the water solubility results. Ohmic heating was described to interfere with the protein aggregate pathways like reducing the aggregates size or change the aggregates shape [32], which could facilitate the keratin interaction with formaldehyde and increase the films' reticulation.

Analyzing the effect of formaldehyde in the swelling ratio of the keratin films, significant differences were observed for all the tested conditions $(\mathrm{pH}$, type of keratin and heating method). Consistent with the water solubility, the swelling ratio is an indication of the level of protein cross-linking in protein-based films. Relatively to the films prepared with keratin from virgin hair and submitted to conventional or ohmic heating, it was verified a decrease between 84 and 95\% in the swelling ratio while for the films prepared with keratin from OB hair, the effect of formaldehyde was more notorious, with a decrease around $97 \%$. The decrease in films swelling was already expected since
A
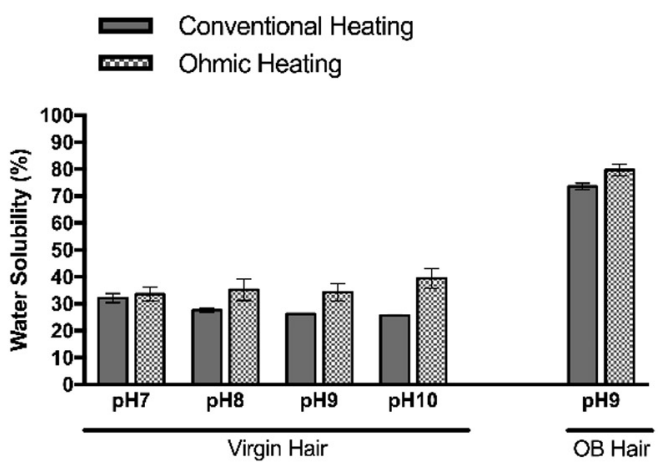

Before formaldehyde
B
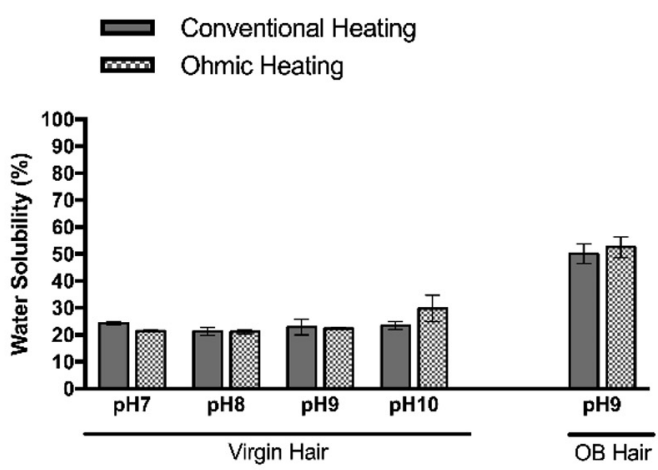

After formaldehyde

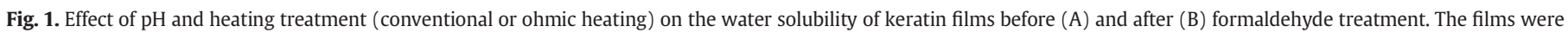

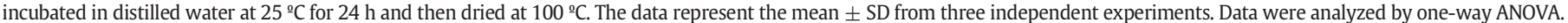


A

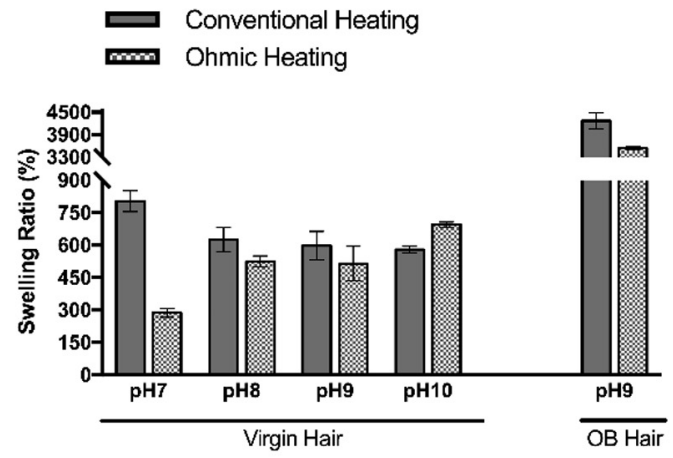

Before formaldehyde
B
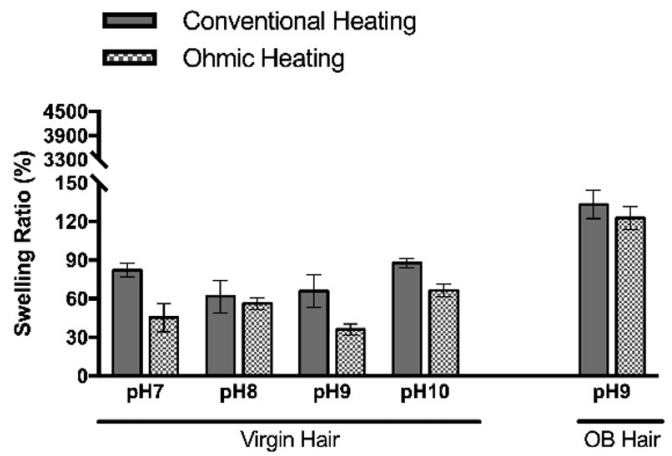

After formaldehyde

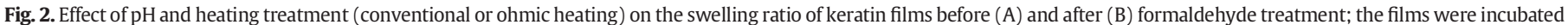
in distilled water at $25^{\circ} \mathrm{C}$ for $1 \mathrm{~h}$ and then weighed. The data represent the mean \pm SD from three independent experiments. Data were analyzed by one-way ANOVA.

formaldehyde reacts with the protein amino groups, so they are not available to bind to water by hydrogen bonding. Also, due to the formation of cross-links in the protein structure, hydrophilic sites along protein chains become less exposed and, therefore, less accessible to water molecules [33].

Despite no differences were observed for the water solubility, the films prepared by conventional and ohmic heating after insolubilization presented significative differences $(p<.001)$ in the swelling ratio when prepared from keratin extracted from virgin hair and adjusted to $\mathrm{pH} 7$ and $\mathrm{pH}$ 9. These results could be an indication that the main differences between the films submitted to conventional or ohmic heating are related to the orientation of keratin molecules and the different proportion of reactive groups in the surface of the keratin films, available to cross-link. Due to the presence of moderate electric fields, ohmic heating can influence the denaturation and aggregation mechanisms of keratin proteins, affecting keratin films properties [3]. It was also demonstrated by Pereira et al. [3], for whey protein solutions, that ohmic heating induces less protein denaturation and less activation of free $\mathrm{SH}$ groups, affecting the protein secondary structure in the films network and, consequently, the films properties. The reorganization of hydrogen bonds, hydrophobic interactions and ionic bonds are also responsible for some conformational disturbances on the tertiary structure of proteins during ohmic heating $[1,3]$. All these variations between ohmic and conventional heating could also justify the differences in the water solubility and swelling ratio results obtained for the keratin films.

Relatively to the effect of $\mathrm{pH}$ of keratin film-forming solutions on the properties of keratin films prepared by conventional heating and ohmic heating, different profiles were observed before the insolubilization with formaldehyde. For the films prepared by conventional heating there was a decrease on the water solubility and swelling ratio, increasing the $\mathrm{pH}$ of keratin solutions. For the films prepared by ohmic heating an increase of water solubility and swelling ratio was observed increasing the $\mathrm{pH}$ of keratin solutions. However, after insolubilization the differences observed for both heating methods became less evident.

From the results we can infer that the changes in keratin films properties after $\mathrm{pH}$ adjustment are related to physicochemical characteristics of keratin protein like surface hydrophobicity, conformation and net charge [26]. Moreover, the opposite tendencies between the films prepared by conventional heating and ohmic heating, could be related with different patterns of denaturation, interactions and aggregation of the keratin protein, which affect in a different way the inter- and intramolecular bounds and the water molecules interaction with the keratin films. It seems that the presence of moderate electric fields might have promoted an increase in film's surface hydrophilicity with the increase of $\mathrm{pH}$ [3], justifying the swelling results for the ohmic heating. In the same way, for the conventional heating, it seems that the increasing the $\mathrm{pH}$ promoted an increase of the amino reactive groups present at the surface of the keratin molecules, resulting in a higher percentage of cross-linking and a consequent decrease in water solubility and swelling ratio of the keratin films [31].

\subsubsection{Secondary structure analysis}

Fourier transform infrared (FTIR) was used to evaluate structural changes in the keratin films prepared at different $\mathrm{pH}(7,8,9$ or 10$)$ and by different heating methods (conventional or ohmic heating) Fig. 3.

As depicted in Fig. 3, the FTIR spectra of the keratin films shows the main characteristic bands associated to the vibrational modes of peptide bonds in proteins namely, amide I $\left(1700-1600 \mathrm{~cm}^{-1}, \mathrm{C}=0\right.$ stretching vibration), amide II $\left(1600-1500 \mathrm{~cm}^{-1}, \mathrm{~N}-\mathrm{H}\right.$ bending and $\mathrm{C}-\mathrm{N}$ stretching vibrations) and amide III (1200-1300 $\mathrm{cm}^{-1}$, in phase combination of $\mathrm{C}-\mathrm{N}$ stretching and $\mathrm{N}-\mathrm{H}$ bending vibrations) [34,35]. For all samples, the spectra present a peak with maxima at $1647 \mathrm{~cm}^{-1}$ for amide I, $1538 \mathrm{~cm}^{-1}$ for amide II, and $1215 \mathrm{~cm}^{-1}$ for amide III. Additionally, the broad band at $3600-3000 \mathrm{~cm}^{-1}$ corresponds to amide $\mathrm{A}$ and was assigned to $\mathrm{O}-\mathrm{H}$ and $\mathrm{N}-\mathrm{H}$ stretching vibrations [34]. The peaks with maxima at $2919 \mathrm{~cm}^{-1}$ and $2851 \mathrm{~cm}^{-1}$ were assigned to $\mathrm{C}-\mathrm{H}$ stretching vibrations [36] and the two absorption bands with maxima at $1455 \mathrm{~cm}^{-1}$ and $1411 \mathrm{~cm}^{-1}$ were assigned to $\mathrm{C}-\mathrm{H}$ bending vibrations [37]. Finally, the absorption band with maximum at $1024 \mathrm{~cm}^{-1}$ was attributed to $\mathrm{C}-\mathrm{O}$ stretching vibration (related to alcohol functional group) and results from the presence of glycerol in the film samples [38]. Noteworthy, the absence of an absorption band at $1745 \mathrm{~cm}^{-1}$, which is due to lipid ester carbonyl vibrations [39], indicates that lipids were effectively removed during the preparation of hair samples prior keratin extraction. The effect of ohmic heating was also evaluated by FTIR in order to determine if the heating source would induce any structural changes in the keratin films (Fig. $3 \mathrm{~A}$ ). In this case, all films presented a similar spectral as those obtained for the films submitted to the conventional heating, independently of the $\mathrm{pH}$ used for film production.

In order to improve films cohesion and resistance, keratin films were treated with formaldehyde, an effective cross-linker to protein films $[30,33,40]$. Addition of formaldehyde during solvent casting demonstrated to have minor effects at the structural level with changes being observed at $1411 \mathrm{~cm}^{-1}$ (C-H bending), $1215 \mathrm{~cm}^{-1}$ (amide III), $1024 \mathrm{~cm}^{-1}$ (C-O stretching) and $921 \mathrm{~cm}^{-1}$ (C-H out-of-plane deformation of alkene group $\mathrm{RCH}=\mathrm{CH}_{2}$ ) (Fig. 3 B). 

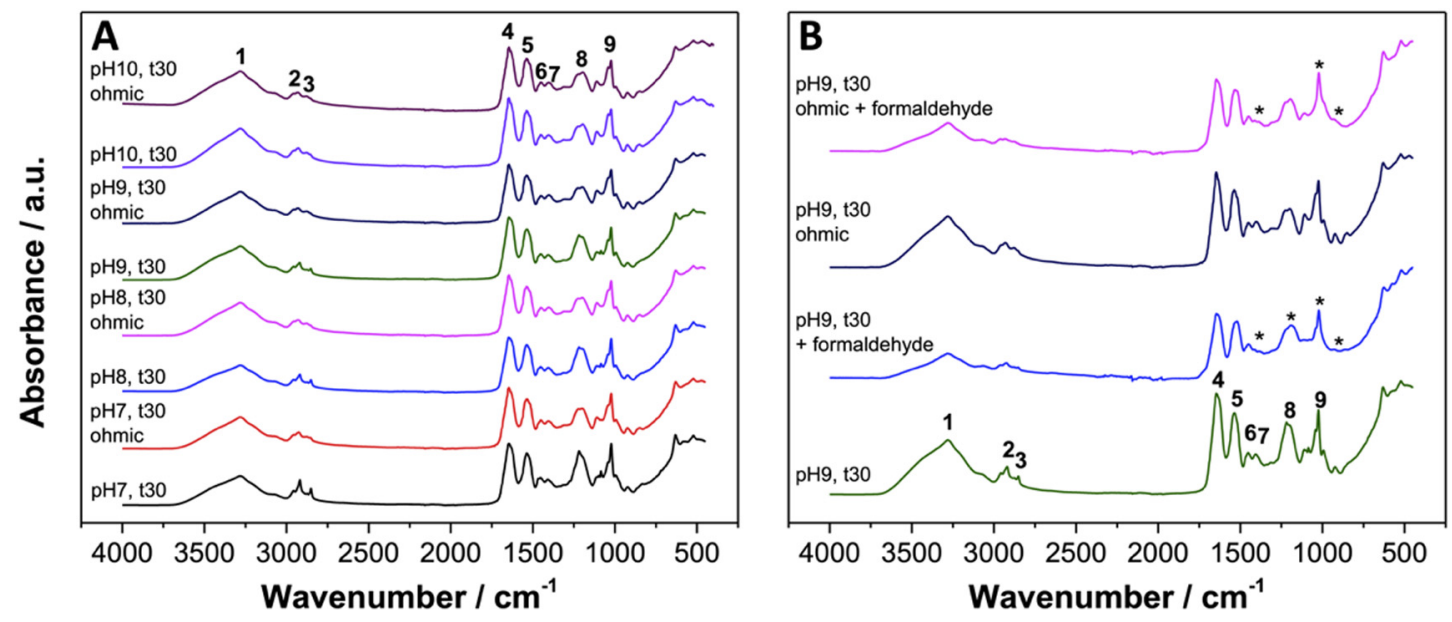

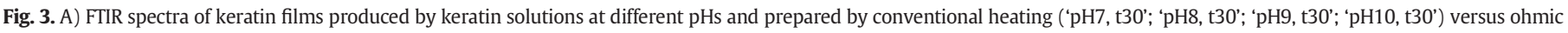

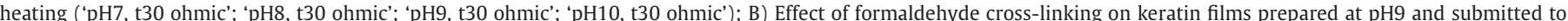

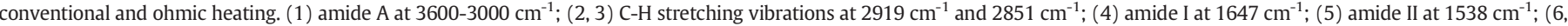

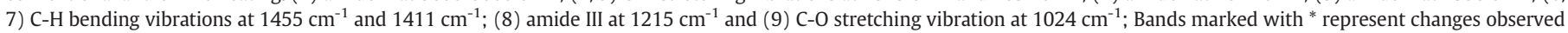
during solvent casting with addition of formaldehyde.

The position of the amide bands I and II are indicative of the secondary structure conformations and are commonly used to identify the protein secondary structure [41]. Accordingly, the peaks at $1647 \mathrm{~cm}^{-1}$ (amide I) and $1538 \mathrm{~cm}^{-1}$ (amide II) are indicative of the $\alpha$-helix conformation [42]. However, the presence of shoulder bands at $1626 \mathrm{~cm}^{-1}$ and $1517 \mathrm{~cm}^{-1}$ also indicates some degree of $\beta$-sheet secondary structures after incubation with formaldehyde supporting the partial insolubilization of the keratin films [41]. This suggests that the keratin films are mainly characterized by $\alpha$-helical conformation, independently of the $\mathrm{pH}$ and source of heating treatment, and that there is some degree of conversion of the $\alpha$-helical into $\beta$-sheet after insolubilization with formaldehyde.

\subsubsection{Thermal stability of keratin films}

In order to study the thermal stability of the keratin films prepared by different heating methods, the thermogravimetric analysis of the films was performed between 25 and $800{ }^{\circ} \mathrm{C}$ Fig. 4 . Comparing the films prepared by conventional heating with the films prepared by ohmic heating, the major differences were mainly noticed for temperatures higher than $500^{\circ} \mathrm{C}$. Initially it was observed, a weight loss between 5.1 and $8.1 \%$ for the conventional heating and $4.6-5.4 \%$ for the ohmic heating, related with the loss of bound water associated with the keratin films, for temperatures below $150{ }^{\circ} \mathrm{C}$ [43]. For temperatures between 150 and $500{ }^{\circ} \mathrm{C}$ there was a weight loss around $60-70 \%$ for the films prepared by the two heating methods. This weight loss was most likely

A

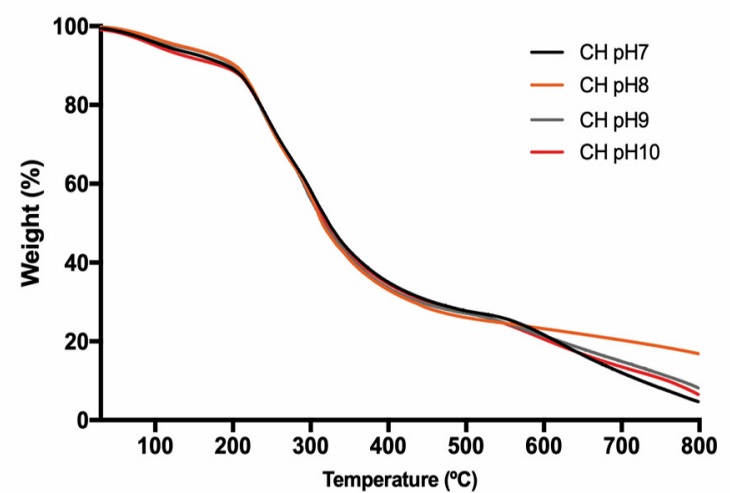

associated with the destruction of lateral chains of the keratin protein molecules in the protein-based films [43]. At the end of the temperature scan, the films retained about 4.6-16.9\% of their initial weight, being this percentage associated to the carbon molecules in the protein and structures that did not decomposed even at $800{ }^{\circ} \mathrm{C}$, which remained as ash [43]. Also, all the keratin films, prepared by conventional or ohmic heating, presented various decomposition peaks in the analyzed temperature range due to the presence of proteins with different sizes, what is a characteristic of the keratin proteins [5].

In the thermograms for the keratin films prepared by conventional heating, it was determined a temperature between 207 and $210{ }^{\circ} \mathrm{C}$ corresponding to initial degradation of the films. This value decreased to $187-206{ }^{\circ} \mathrm{C}$ for the keratin films prepared by ohmic heating, what could be an indication of the lower stability for these films as well as a lower amount of crystalline-sheet structures [44]. For these films, less energy is needed to start to disintegrate the protein matrix. Also, the multi-stage degradation profiles presented a main peak around $300-310^{\circ} \mathrm{C}$, corresponding to the maximum degradation rate, and a pronounced shoulder around $230-235^{\circ} \mathrm{C}$. Both peaks correspond to the disorganization and destruction of the crystalline regions of the keratin protein [43]. The intensity of this shoulder around $230-235{ }^{\circ} \mathrm{C}$ was less intense or inexistent for the keratin films prepared at $\mathrm{pH} 7$, confirming the effect of $\mathrm{pH}$ on the formation of structures in the films mainly due to inter- and intramolecular bounds [43].

B

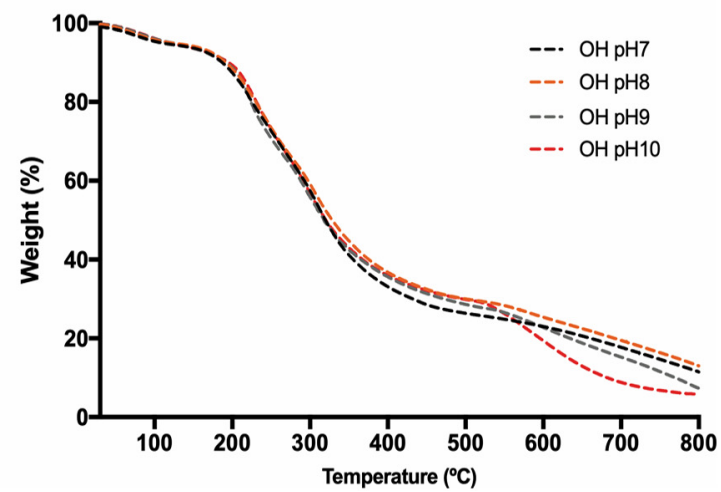

Fig. 4. Effect of $\mathrm{pH}$ of the keratin film-forming solutions on the thermal stability of keratin films prepared by $(\mathrm{A})$ conventional heating $(\mathrm{CH})$ or $(\mathrm{B})$ ohmic heating $(\mathrm{OH})$. 


\subsubsection{Morphological observation}

The morphology of the keratin films prepared using keratin extracted from virgin or overbleached hair, adjusted to $\mathrm{pH}$ 9, and heated using the conventional and the ohmic heating were examined using SEM and the micrographs are represented on Fig. 5.

Through the analysis of the SEM micrographs it was possible to verify that all the keratin films (Virgin and OB Hair) submitted to the different heating conditions form a compact and continuous structure and no phase separation between the keratin proteins and the glycerol was observed. The keratin films prepared by conventional heating shows more homogeneous surfaces and are more compact when comparing with the same films prepared by ohmic heating (Ohmic Heating/Virgin Hair: $75.14 \pm 2.65 \mu \mathrm{m}$ versus Conventional Heating/Virgin Hair: $51.59 \pm 2.36 \mu \mathrm{m}$ and Ohmic Heating/OB Hair: $74.43 \pm 1.52 \mu \mathrm{m}$ versus Conventional Heating/OB Hair: $38.28 \pm 2.81 \mu \mathrm{m})$.

The micrographs of the keratin films after cross-linking with formaldehyde revealed the appearance of small aggregates at the surface of the films which are most likely related with the evaporation of the crosslinker. This evaporation effect was more marked for the keratin films prepared using keratin extracted from virgin hair and submitted to ohmic heating, as they presented a surface with several wrinkle-like structures. These differences in films surfaces caused by cross-linking with formaldehyde were already reported by Carvalho and Grosso, and are caused by a cohesive arrangement of the polymeric matrix [40].

\subsection{Opacity using a fusion protein}

Evaluating cosmetic treatments which modify some physical features of hair fibers can be challenging due to the intrinsic properties of human hair like size and shape, and also due to hairs' great heterogeneity. A fusion protein composed by human eye $\gamma \mathrm{D}$-crystallin and a keratin-based peptide (KP) was used to modify the opacity of hair fibers as a principle to develop new hair coloration strategies- Fig. 6. Two fusion proteins were used, a wild type form (KP-Cryst Wt) based on the sequence human eye $\gamma \mathrm{D}$-crystallin and a mutant form (KP-Cryst Mut). The mutant form was constructed by the substitution of three arginine residues by three Cys, on the wild-type crystallin sequence, what would increase the formation of protein inter- and intramolecular bonds and its interaction with the hair keratin [23]. Proteins with
Greek-key motifs like crystalline were already described to have the ability to form a coating around different structures, and to form opaque structures denominated cataracts when the proteins start to unfold, promoting protein aggregation [23]. The combination of both factors, make the crystallin proteins perfect models to study fibers opacity caused by the application of these proteins.

A qualitative and quantitative analysis of keratin films opacity is shown in Fig. 6, where it is possible to observe some changes in films opacity after application of KP-Cryst Wt and KP-Cryst Mut fusion proteins.

Relatively to the KP-Cryst Wt, no significative differences were verified for the films prepared with keratin extracted from virgin or OB hair, neither the ones prepared by conventional or ohmic heating. However, a different behavior was observed for the films where KP-Cryst Mut was applied. Higher opacity values were observed for films treated with KPCryst Mut protein, with a higher opacity degree obtained for the keratin films produced with keratin extracted from virgin hair and submitted to conventional heating. The higher opacity degree obtained for KP-Cryst Mut films could be due to structural characteristics of these proteins, where the mutations were performed to induce the protein aggregation, mimicking the formation of cataracts in eye. Also, KP-Cryst Mut has three additional Cys which favors the binding of these molecules to keratin proteins, increasing the protein adhesion the films' surface [23].

Based on these results, we can assume that the keratin films can be used as models to determine the effect of cosmetic formulations specially developed to change the opacity of the hair fibers.

\section{Conclusions}

The heating of protein solutions influenced the unfolding and aggregation patterns of the proteins, affecting the film features. Considering the ohmic heating, it was demonstrated that this heating method affected differentially the denaturation of keratin proteins, resulting in films with different properties comparatively to the ones prepared by conventional heating.

The application of KP-Cryst proteins over the keratin films, demonstrated the films' ability to act as a model to substitute the use of hair on the testing of new hair cosmetic formulations. With this work, it

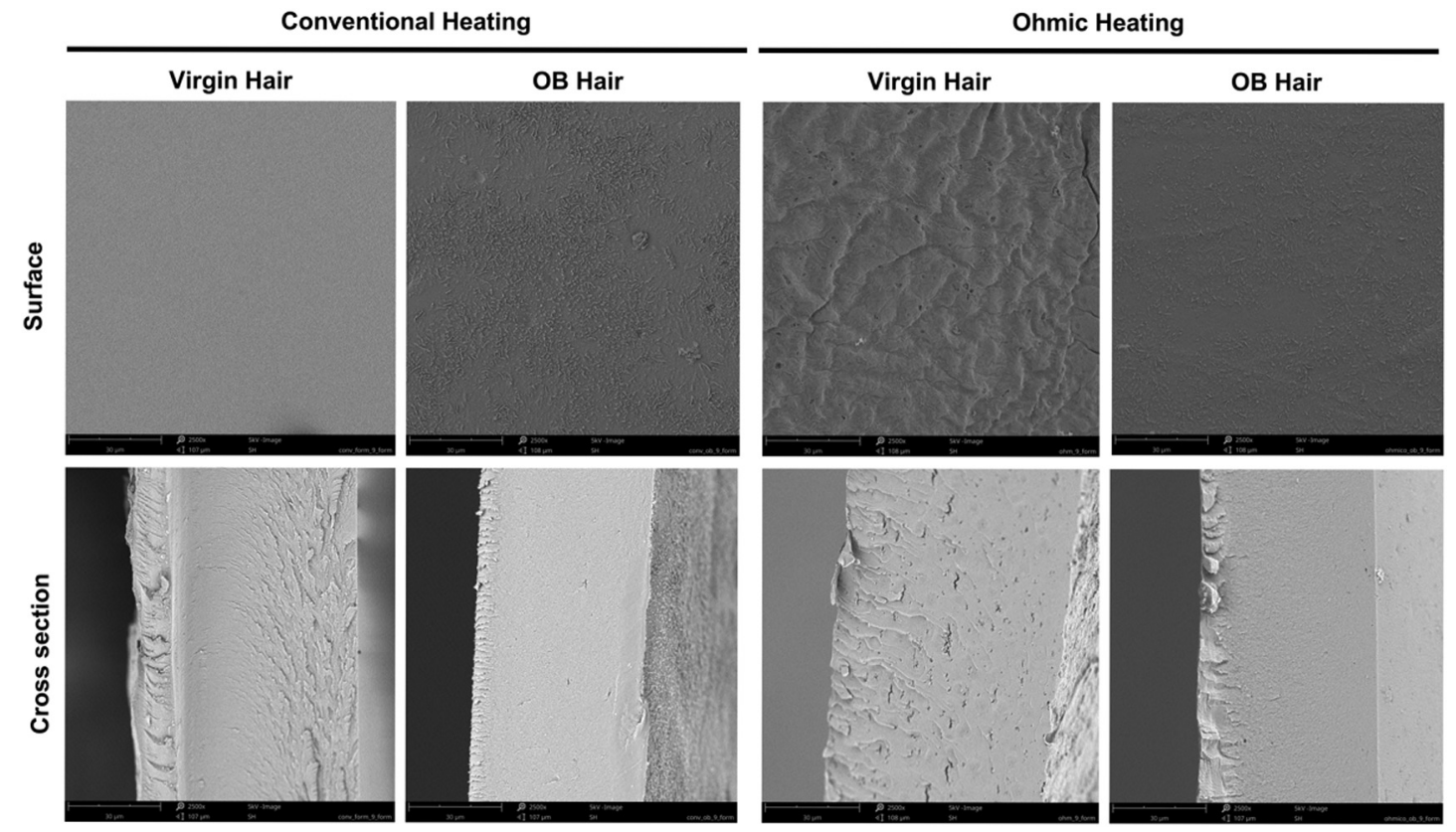

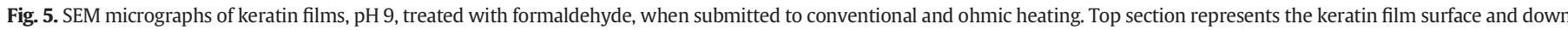

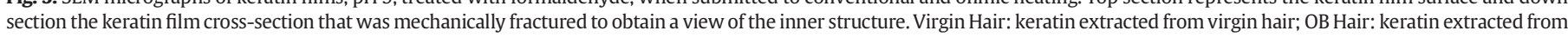
overbleached hair. 
A

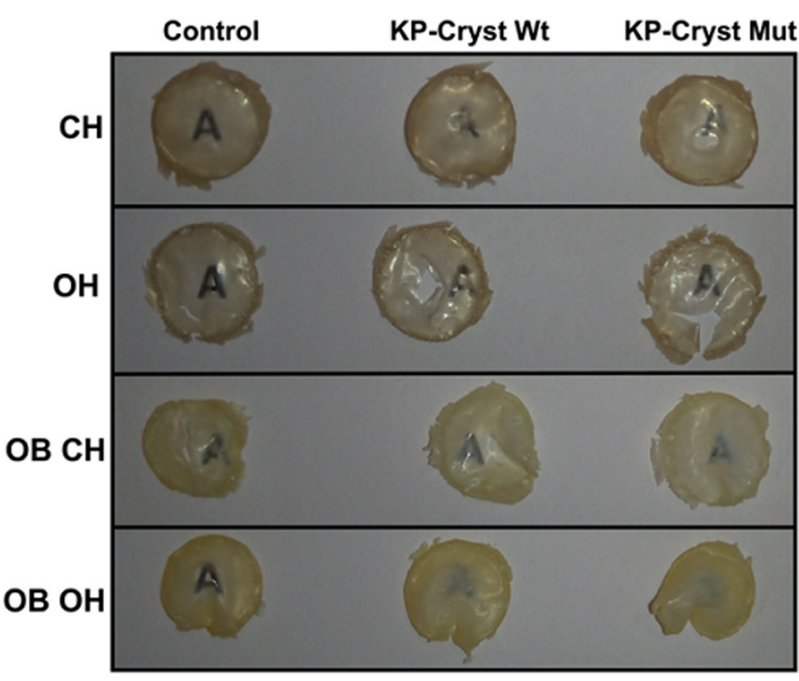

B

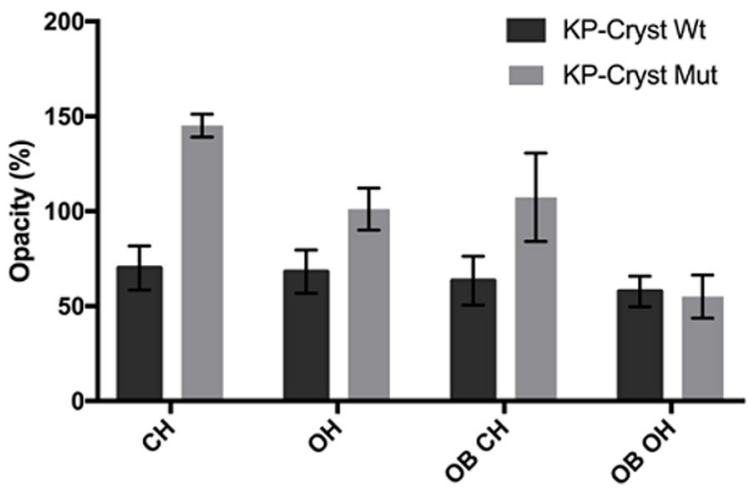

Fig. 6. A) Effect of KP-Cryst Wt and KP-Cryst Mut proteins application on keratin films opacity. A total of $0.6 \mathrm{mg}$ of protein were applied to the keratin films. Ultra-pure water was applied in the same volume as the protein solution, for the control samples; B) Mean values of keratin films opacity after incubation with KP-Cryst Wt and KP-Cryst Mut proteins. The increasing percentages were calculated in comparison with the control samples. $\mathrm{CH}$ - conventional heating; $\mathrm{OH}$ - ohmic heating; $\mathrm{OB}$ - keratin extracted from Overbleached Hair.

was demonstrated that both conventional and ohmic heating techniques are able to be used in the production of keratin films with adjusted properties according the heating method. The keratin films show potential to be applied in the validation of hair cosmetic formulations as substitutes of hair fibers.

\section{CRediT authorship contribution statement}

Ana Tinoco: Methodology, Validation, Formal analysis, Investigation, Writing - original draft. Rui M. Rodrigues: Methodology, Investigation. Raul Machado: Methodology, Investigation, Writing - original draft. Ricardo N. Pereira: Methodology, Writing - review \& editing. Artur Cavaco-Paulo: Writing - review \& editing, Supervision. Artur Ribeiro: Conceptualization, Methodology, Writing - review \& editing, Supervision.

\section{Acknowledgements}

This study was supported by the Portuguese Foundation for Science and Technology (FCT) under the scope of the strategic funding of UIDB/ 04469/2020 unit and BioTecNorte operation (NORTE-01-0145-FEDER000004) funded by the European Regional Development Fund under the scope of Norte2020 - Programa Operacional Regional do Norte. Ana Tinoco and Rui M. Rodrigues thanks FCT for funding the scholarships with the references SFRH/BD/114035/2015 and SFRH/BD/ $110723 / 2015$, respectively.

\section{Declaration of competing interest}

None.

\section{References}

[1] R.M. Rodrigues, A.J Martins, O.L. Ramos, F.X. Malcata, A. Vicente, R.N. Pereira, Influence of moderate electric fields on gelation of whey protein isolate, Food Hydrocoll. 43 (2015) 329-339, https://doi.org/10.1016/j.foodhyd.2014.06.002.

[2] D.L. Parrott, Use of Ohmic heating for aseptic processing of food particulates, Food Technol. 46 (1992) 68-72.

[3] R.N. Pereira, B.W.S. Souza, M.A. Cerqueira, A. Teixeira, Effects of electric fields on protein unfolding and aggregation: influence on edible films formation, Biomacromolecules 11 (2010) 2912-2918.

[4] B.C. Powell, G.E. Rogers, The role of keratin proteins and their genes in the growth, structure and properties of hair, Formation and Structure of Human Hair, Birkhauser Verlag, Basel, Switzerland 1997, pp. 59-148, https://doi.org/10.1007/978-3-03489223-0_3.

[5] H.H. Bragulla, D.G. Homberger, Structure and functions of keratin proteins in simple, stratified, keratinized and cornified epithelia, J. Anat. 214 (2009) 516-559, https:// doi.org/10.1111/j.1469-7580.2009.01066.x.

[6] S.M. Martelli, G.R.P. Moore, J.B. Laurindo, Mechanical properties, water vapor permeability and water affinity of feather keratin films plasticized with sorbitol, J. Polym. Environ. 14 (2006) 215-222, https://doi.org/10.1007/s10924-006-0017-4.

[7] S. Naito, T. Nemoto, Odor-Removing and Deodorizing Composition Employing a Hydrolysate of Keratin Material, Patent Number: 4,591,497, 1986.

[8] P. Mokrejs, M. Hutta, J. Pavlackova, P. Egner, L. Benicek, The cosmetic and dermatological potential of keratin hydrolysate, J. Cosmet. Dermatol. 16 (2017) e21-e27, https://doi.org/10.1111/jocd.12319.

[9] A. Tinoco, J. Gonçalves, C. Silva, A. Loureiro, A.C. Gomes, A. Cavaco-Paulo, A. Ribeiro, Keratin-based particles for protection and restoration of hair properties, Int. J. Cosmet. Sci. 40 (2018) 408-419, https://doi.org/10.1111/ics.12483.

[10] M.A. Abouheif, S. Basmaeil, H. Metwally, S. Masoud, Chemical preparation of $\mathrm{NaOH}-$ keratin hydrolysate for improving the nutritive value of wheat straw, Anim. Feed Sci. Technol. 13 (1985) 215-225, https://doi.org/10.1016/0377-8401(85)90024-0.

[11] N.-B. Song, J.-H. Lee, M. Al Mijan, K. Bin Song, Development of a chicken feather protein film containing clove oil and its application in smoked salmon packaging, LWT Food Sci. Technol. 57 (2014) 453-460, https://doi.org/10.1016/J.LWT.2014.02.009.

[12] M.P. Than, R.A Smith, C. Hammond, R. Kelly C Marsh, A.D. Maderal, R.S. Kirsner Keratin-based wound care products for treatment of resistant vascular wounds, J. Clin. Aesthet. Dermatol. 5 (2012) 31.

[13] M. Borrelli, N. Joepen, S. Reichl, D. Finis, M. Schoppe, G. Geerling, S. Schrader, Keratin films for ocular surface reconstruction: evaluation of biocompatibility in an in-vivo model, Biomaterials 42 (2015) 112-120, https://doi.org/10.1016/j.biomaterials. 2014.11.038.

[14] P. Sierpinski, J. Garrett, J. Ma, P. Apel, D. Klorig, T. Smith, L.A. Koman, A. Atala, M. Van Dyke, The use of keratin biomaterials derived from human hair for the promotion of rapid regeneration of peripheral nerves, Biomaterials 29 (2008) 118-128, https:// doi.org/10.1016/j.biomaterials.2007.08.023.

[15] A. Tachibana, Y. Nishikawa, M. Nishino, S. Kaneko, T. Tanabe, K. Yamauchi, Modified keratin sponge: binding of bone morphogenetic protein-2 and osteoblast differentiation, J. Biosci. Bioeng. 102 (2006) 425-429, https://doi.org/10.1263/JBB.102.425.

[16] Z. Cheng, X. Chen, D. Zhai, F. Gao, T. Guo, W. Li, S. Hao, J. Ji, B. Wang, Development of keratin nanoparticles for controlled gastric mucoadhesion and drug release, J. Nanobiotechnology. 16 (2018) 24, https://doi.org/10.1186/s12951-018-0353-2.

[17] S.I.N. Ayutthaya, S. Tanpichai, J. Wootthikanokkhan, Keratin extracted from chicken feather waste: extraction, preparation, and structural characterization of the keratin and keratin/biopolymer films and electrospuns, J. Polym. Environ. 23 (2015) 506-516, https://doi.org/10.1007/s10924-015-0725-8.

[18] A Lusiana, S. Reichl, C.C. Müller-Goymann, Keratin film made of human hair as a nail plate model for studying drug permeation, Eur. J. Pharm. Biopharm. 78 (2011) 432-440. doi:https://doi.org/10.1016/j.ejpb.2011.01.022.

[19] P. Hernández-Muñoz, A. Kanavouras, J.M. Lagaron, R. Gavara, Development and characterization of films based on chemically cross-linked gliadins, J. Agric. Food Chem. 53 (2005) 8216-8223.

[20] A. Tinoco, J. Gonçalves, C. Silva, A. Loureiro, A.C. Gomes, A. Cavaco-Paulo, A. Ribeiro, Keratin-based particles for protection and restoration of hair properties, Int. J. Cosmet. Sci. 40 (2018) 408-419, https://doi.org/10.1111/ics.12483.

[21] M. Fernandes, A. Cavaco-Paulo, Protein disulphide isomerase-mediated grafting of cysteine-containing peptides onto over-bleached hair, Biocatal. Biotransformation. 30 (2012) 10-19, https://doi.org/10.3109/10242422.2012.644436.

[22] G.R.P. Moore, S.M. Martelli, C. Gandolfo, P.J. do A. Sobral, J.B. Laurindo, Influence of the glycerol concentration on some physical properties of feather keratin films, Food Hydrocoll. 20 (2006) 975-982, https://doi.org/10.1016/j.foodhyd.2005.11.001.

[23] A. Tinoco, J. Gonçalves, C. Silva, A. Cavaco-paulo, A. Ribeiro, Crystallin fusion proteins improve the thermal properties of hair, Front. Bioeng. Biotechnol. 7 (2019) 1-12, https://doi.org/10.3389/fbioe.2019.00298.

[24] J.C. Bischof, X. He, Thermal stability of proteins, Ann. N. Y. Acad. Sci. 1066 (2005) 12-33, https://doi.org/10.1196/annals.1363.003.

[25] C.R. Robbins, Chemical and Physical Behavior of Human Hair, Springer, New York, USA, 2012https://doi.org/10.1007/978-3-642-25611-0. 
[26] D. Kowalczyk, B. Baraniak, Effects of plasticizers, $\mathrm{pH}$ and heating of film-forming solution on the properties of pea protein isolate films, J. Food Eng. 105 (2011) 295-305, https://doi.org/10.1016/j.jfoodeng.2011.02.037.

[27] H.B. Bull, K. Breese, Electrical conductance of protein solutions, J. Colloid Interface Sci. 29 (1969) 492-495, https://doi.org/10.1016/0021-9797(69)90133-7.

[28] D.W. Atchley, E.G. Nichols, The influence of protein concentration on the conductivity of human serum, J. Biol. Chem. 65 (1925) 729-734.

[29] S.M. Marino, V.N. Gladyshev, Analysis and functional prediction of reactive cysteine residues, J. Biol. Chem. 287 (2012) 4419-4425, https://doi.org/10.1074/jbc.R111. 275578.

[30] Z. Ustunol, B. Mert, Water solubility, mechanical, barrier, and thermal properties of cross-linked whey protein isolate-based films, J. Food Sci. 69 (2004) FEP129-FEP133.

[31] F.R.B. Turbiani, J. Tomadon, F.L. Seixas, M.L. Gimenes, Properties and structure of sericin films: effect of the crosslinking degree, Chem. Eng. Trans. 24 (2011) 1489-1494, https://doi.org/10.3303/CET1124249.

[32] R.N. Pereira, R.M. Rodrigues, Ó. Ramos, F. Xavier Malcata, J.A. Teixeira, A.A. Vicente, Production of whey protein-based aggregates under Ohmic heating, Food Bioprocess Technol. 9 (2016) 576-587, https://doi.org/10.1007/s11947-015-16514.

[33] P. Hernández-Muñoz, A. López-Rubio, J.M. Lagarón, R. Gavara, Formaldehyde crosslinking of Gliadin films: effects on mechanical and water barrier properties, Biomacromolecules 5 (2004) 415-421, https://doi.org/10.1021/bm0342537.

[34] E. Wojciechowska, A. Włochowicz, A. Wesełucha-Birczyńska, Application of Fouriertransform infrared and Raman spectroscopy to study degradation of the wool fiber keratin, J. Mol. Struct. 511 (1999) 307-318, https://doi.org/10.1016/S0022-2860 (99)00173-8.

[35] J. Ko, L.T.H. Nguyen, A. Surendran, B.Y. Tan, K.W. Ng, W.L. Leong, Human hair keratin for biocompatible flexible and transient electronic devices, ACS Appl. Mater. Interfaces 9 (2017) 43004-43012, https://doi.org/10.1021/acsami.7b16330.
[36] K. Song, H. Xu, K. Xie, Y. Yang, Keratin-based biocomposites reinforced and crosslinked with dual-functional cellulose nanocrystals, ACS Sustain. Chem. Eng. 5 (2017) 5669-5678, https://doi.org/10.1021/acssuschemeng.7b00085.

[37] E.G. Bendit, Infrared absorption spectrum of keratin. I. Spectra of $\alpha-, \beta-$, and supercontracted keratin, Biopolym. Orig. Res. Biomol. 4 (1966) 539-559, https:// doi.org/10.1002/bip.1966.360040506.

[38] R. Machado, A. da Costa, V. Sencadas, A.M. Pereira, T. Collins, J.C. Rodríguez-Cabello, S. Lanceros-Méndez, M. Casal, Exploring the properties of genetically engineered silk-elastin-like protein films, Macromol. Biosci. 15 (2015) 1698-1709, https://doi. org/10.1002/mabi.201500132.

[39] C.D. Tran, T.M. Mututuvari, Cellulose, chitosan and keratin composite materials: facile and recyclable synthesis, conformation and properties, ACS Sustain. Chem. Eng. 4 (2016) 1850-1861, https://doi.org/10.1021/acssuschemeng.6b00084.

[40] R.A. Carvalho, C.R.F. Grosso, Properties of chemically modified gelatin films, Brazilian J. Chem. Eng. 23 (2006) 45-53. www.abeq.org.br/bjche.

[41] J.T. Pelton, L.R. McLean, Spectroscopic methods for analysis of protein secondary structure, Anal. Biochem. 277 (2000) 167-176, https://doi.org/10.1006/ABIO.1999. 4320.

[42] J.M. Cardamone, Investigating the microstructure of keratin extracted from wool: peptide sequence (MALDI-TOF/TOF) and protein conformation (FTIR), J. Mol. Struct. 969 (2010) 97-105, https://doi.org/10.1016/J.MOLSTRUC.2010.01.048.

[43] A. Thonpho, P. Srihanam, Preparation and characterization of keratin blended films using biopolymers for drug controlled release application, Orient. J. Chem. 32 (2016) 1739-1748, https://doi.org/10.13005/ojc/320402.

[44] A. Aluigi, M. Zoccola, C. Vineis, C. Tonin, F. Ferrero, M. Canetti, Study on the structure and properties of wool keratin regenerated from formic acid, Int. J. Biol. Macromol. 41 (2007) 266-273, https://doi.org/10.1016/j.ijbiomac.2007.03.002. 